\title{
Study on Information Literacy Improvement of College Teachers Under COVID-19 Epidemic Situation
}

\author{
Xiangli Dong*
}

Shandong union college, yaoqiang town, licheng district, jinan city, China

*Corresponding author. Email: 778118795@qq.com

\begin{abstract}
Informatization is the trend of the development of education in today's society, global education has been deeply marked by the development of informatization. Information technology, changing the direction of the development of higher education, as well as shaping the future of education. At present, COVID-19 epidemic prevention and control form is severe. In the face of the outbreak of the impact of education teaching in China, the Ministry of Education issued relevant policy quickly.Schools around the country are postponing classes.The order of normal education of college students had a great impact.However, it is still the most important task for college students to ensure their studies while ensuring the life safety of teachers and students at present.The Ministry of Education requirements teaching without suspension, school without suspension during the epidemic prevention and control. The implementation of online teaching in colleges and universities puts forward higher requirements for teachers' information-based teaching ability.
\end{abstract}

Keywords: COVID-19, college teachers, information literacy

\section{INTRODUCTION}

In 2020, the Chinese people will remember that the outbreak of COVID - 19 in wuhan, hubei province is an extremely rare major health event. From centenarians to newborn babies, everyone is susceptible, regardless of age, nationality or race. The high number of confirmed, suspected and confirmed deaths every day is frightening to watch. "Life is more important than mount tai, and the epidemic is an order, and the prevention and control of the epidemic is the responsibility." We will fully implement the spirit of President xi's speec. We are united in fighting against the epidemic. Education is the great plan of the country and the Party. The report of the 19th national congress of the party points out that the achievements of education are in the present and in the future. Aimed at the impact of COVID-19 epidemic on the normal opening and classroom teaching in colleges and universities, The ministry of education issued the guidance on organizing and managing online teaching in regular institutions of higher learning during epidemic prevention and control. It requires the government, universities and society to ensure the online teaching during the "anti-epidemic" period, so as to realize the "suspension of classes without suspension of teaching" [1]. Online teaching has high requirements on technology, takes a lot of time, and has high requirements on the online teaching environment, which is a challenge for every teacher. Nowadays, with the rapid development of Internet and smart Internet, social informatization is an important feature of the current era, and the demand for talents has been endowed with new connotation of The Times. School education is the main front for college students to acquire knowledge, and school education teachers are the first resource. Under the COVID 19 epidemic, new requirements are put forward for teachers' information literacy.

\section{INFORMATION LITERACY CONCEPT}

With the development of information technology, the content and dimension of information literacy are constantly updated and expanded. The original concept of information literacy was introduced in 1974 by Paul zeckowski, President of the information industry association. Defined as the ability to get questions answered using a large number of information tools and main sources of information. According to him, complete information literacy includes cultural literacy (knowledge level), information awareness (awareness level) and information skills (technology level) [2]. In 1987, PatrieiaBreivik, an information scientist, defined information literacy as "understanding the system that provides information and being able to identify the value of information, choosing the best access to information, and mastering the basic skills of obtaining and storing information".In 1989, the American library association redefined it as "the comprehensive ability of an individual to recognize when information is needed and to retrieve, evaluate, and utilize information effectively." In 1992, Christina Doyle of the United States further defined information literacy as "the ability to obtain, evaluate, and use information from a variety of sources." Now there is a consensus at home and abroad that the connotation of information literacy should cover information awareness, 
information knowledge, information ability and information ethics [3].

\section{CURRENT SITUATION OF EDUCATIONAL INFORMATIZATION IN CHINA}

Educational informatization refers to the process of comprehensively and deeply applying modern information technology to promote educational reform and development in the field of education (education management, education teaching and education research) [4]. Since 2010, the state council and the ministry of education have issued policies to support the development of educational informatization industry every year. In September 2012, the state put forward the goal of education informatization construction during the "12th five-year plan" period, and education informatization entered the 1.0 era. In April 2018, the ministry of education officially issued the action plan of education informatization 2.0, which was upgraded based on education informatization 1.0, and put forward the goal of realizing the "Three master programs, Two master programs and One master program" by 2022 , indicating that education informatization will usher in a new development stage [5]. In 2019, the state council issues China's education modernization 2035, which further requires the acceleration of education reform in the information age. Without information, there will be no modernization. Education informatization is the basic connotation and prominent feature of education modernization, and the key content and important symbol of "education modernization 2035" [6]. Shandong provincial department of education subsequently issued the action plan of shandong province education informatization 2.0 (2019-2022) to improve teachers' information literacy. Education informatization is an important part of national informatization, which plays an important role in supporting and guiding the modernization of education. For higher education, education informatization should comprehensively improve the quality of higher education. With the continuous expansion of online education and educational informatization, the cause of intelligent education in China is flourishing.

\section{INFORMATION LITERACY OF TEACHERS AND STUDENTS IN COLLEGES AND UNIVERSITIES IN CHINA}

\subsection{Information Literacy of College Teachers}

Many scholars at home and abroad have different opinions on the composition of information literacy of teachers in high school.

\subsubsection{Information awareness, ethics and teaching and research literacy}

Information awareness is a kind of consciousness, which is formed by continuous learning in social practice and is the premise of information literacy. It is manifested in the sensitivity, cognition and innovation ability of college teachers to information. Information ethics is the ideological concept and behavior criterion regulating people's mutual relationship in the field of information, including moral consciousness, moral relationship and moral behavior, which is the guarantee of information literacy [7]. Teachers in colleges and universities must conform to the moral standards required by the society in the information-based teaching activities. In the era of "Internet + education" and "artificial intelligence + education", There has been a profound change in the way people learn, Teachers should set up the concept of lifelong learning, positive and active, conscious learning and use of modern information technology, to be able to consciously capture the direction of teaching, scientific research, the effective acquisition, exploration, evaluation, on the basis of existing information divergence of innovative thinking, with unique Angle of view information, form the research results, and the promotion, formation of independent intellectual property rights, don't touch the moral bottom line.

\subsubsection{Information knowledge, ability and curriculum integration literacy}

Information knowledge is the foundation of information literacy, information ability is the core of information literacy, teachers should fully understand the basic knowledge of information theory, such as what is information, the characteristics of information, the composition of computer system and working principle, and understand the use of some commonly used tools and software, For example, MS Office, PhotoShop, Flash, ACDSee, Camtasia Studio, fast clip, browser and other applications, And the effective use of their own information knowledge into their own curriculum, not only can use information technology to spread high-quality education resources to students, but also use information technology to create an information learning environment for students. In addition, information dissemination methods and skills, is also a must for college teachers. COVID-19 off-line teaching quality is the best standard to test teachers' information knowledge, ability and curriculum integration literacy ability.

\subsection{Current Situation of College Teachers' Information Literacy}

Improving teachers' information literacy is an important issue in the development of educational informatization 2.0 
era, and college teachers in the new era are the top priority, which has gradually attracted more and more attention. Every college teacher should correctly recognize the importance of college students' information literacy, and carry out targeted training. Through investigation and literature research, it is found that the information literacy of college teachers has been greatly improved, but with the continuous development of information technology, there are still some problems restricting the development of educational informatization in the information literacy of college teachers, which are summarized as follows.

\subsubsection{College teachers have little awareness of information literacy and the depth of information teaching needs to be improved}

Some college teachers to cognitive education informationization, shallow conformism, hidebound, never thinking by using information technology to reform "cramming education" and "cramming" teaching methods, the comprehensive application of information technology teaching consciousness, the model USES the projector to show in class courseware, scripted, the use of some of the information teaching platform is always passive acceptance, never active exploration, no real grasp the informationization teaching connotation, the informationization teaching depth needs to be promoted.

\subsubsection{The lack of basic theoretical knowledge, information knowledge and teaching and research ability of college teachers need to be improved}

A qualified college teacher must have good professional knowledge and be familiar with relevant knowledge of pedagogy, psychology, educational psychology, teacher's professional ethics and educational laws and regulations. However, some teachers are ignorant of the basic theoretical knowledge of education, Knowledge of education and technology is limited, information knowledge is limited, even if the professional knowledge is rich, the knowledge structure is single, the information collection and processing ability is low, there is no research direction, the teaching problem cannot be transformed into a teaching and scientific research topic, the scientific research results published in a low level, just to cope with the examination, the basic information literacy of the students is not up to standard.

\subsubsection{The lack of information literacy environment in colleges and universities, information literacy assessment mechanism to be improved}

The level of teachers' information literacy directly affects the level of information teaching in a university. Some universities do not pay enough attention to the information literacy of teachers, and the basic software and hardware equipment of information-based teaching are insufficient. Lack of perfect information literacy training, training programs, training content is not systematic, training time is not consistent, lack of application environment, especially for some practical training, training is finished, do not implement the application, lack of a perfect assessment mechanism, training effect is not satisfactory.

\subsection{Current Situation of Students' Information Literacy}

Shandong province education informatization 2.0 action plan (2019-2022) proposes to improve students' information literacy. Information literacy is the essential basic ability and quality of college students in the new era, which is related to whether college students can quickly adapt to the needs of society after graduation. The cultivation of college students' information literacy is the basic direction of talent cultivation in colleges and universities. College students must have basic information literacy while mastering basic professional skills, which plays a crucial role in promoting educational informatization in China [8]. Through the review of various literature and a variety of methods of investigation, we know that in this era of information flooding, in the face of the rich and colorful network information, college students are still at a loss what to do, and they just browse, not to study. In the face of some dirty information, criminal information, lack of awareness of prevention, in the face of some flood information, the ability to screen effective information.

\section{MEASURES TO IMPROVE TEACHERS' INFORMATION LITERACY IN THE CONTEXT OF COVID-19 EPIDEMIC}

COVID-19 epidemic accelerated the reform of information education and teaching, online education showed an explosive development trend, the implementation of traditional classroom teaching is not realistic, must improve the information literacy of college teachers, specific recommendations are summarized in the following aspects. 


\subsection{Improve the Awareness of Information Literacy, Update the Concept of Information Education}

In the new era, college teachers are the backbone in the process of national informatization. As a qualified college teacher, a very important task is to have a strong awareness of information literacy. Establish the concept of "Internet + education", consciously cultivate their own thinking and interest in information, enhance the will of teachers in information development, improve the initiative in the application of information technology and correctly guide the cultivation of students' information literacy. In the process of teaching, we should constantly strengthen the basic theoretical knowledge of relevant education, as well as the study of brain cognitive science knowledge, establish the concept of lifelong learning, improve the learning efficiency, consult more relevant literature, discuss with the teaching and research section, organize knowledge competition, strengthen knowledge cognition, and educate people scientifically.

\subsection{Improve the Information Knowledge Structure, Strengthen the Cognition of the Basic Theoretical Knowledge of Education, and Improve the Ability of Teaching and Research}

In the process of teaching implementation, a good lesson requires not only the professional knowledge and ability of the teacher, but also information knowledge. At the very least, the teacher should be able to make some high-quality demonstration courseware, know the most basic audio, video, graphics and image processing software. The education and teaching arrangement should be systematic, and the methods and methods should be flexible and diverse. Only in this way can students' good study habits, strong interest in learning and strong willingness to learn independently be cultivated, and students' participation in class can be improved to ensure efficient learning. Especially COVID-19 outbreak of online teaching, college teachers should make full use of online for class and provincial school, two levels of high-quality online courses teaching resources, or live, or recording speed class, rich contents, various forms of curriculum resources construction, and relying on the online course platform of all types and at all levels, the campus network learning space, etc., actively carry out online teaching activities, ensure the quality of epidemic prevention and control during the teaching progress and teaching. Strengthen the cognition of the basic theoretical knowledge of education, and effectively apply it to teaching activities, such as the determination of teaching objectives to follow the "dell pyramid", theory to guide practice, optimize the course information teaching design. Good at discovery, good at summary and accumulation, the courage to explore, innovation, reform, only usually do a good job in the input, in order to better output, improve the ability of teaching and research.

\subsection{Colleges and Universities Should Create a Good Information Literacy Environment, Strengthen Information Literacy Training, Improve Information Teaching Assessment Mechanism and Improve Teaching Skills}

The environment creates the person, the school information education teaching reform development leads the teacher information technology application ability enhancement training. Information-based teaching equipment is a necessary teaching facilities, teaching for teachers to provide a unified platform, strengthen every teacher's information literacy training, to strengthen university teachers' teaching methods and information technology applications, online and network teaching, promote the informatization and teaching based on the depth of the fusion, strengthen accurate assessment, improve training efficiency, improve the information-based teaching evaluation mechanism, strengthen the institutional guarantee, enhance each teacher informatization teaching enthusiasm, participation, improve the teaching skills.

\section{SUMMARY}

College teachers' information literacy in the current big data, artificial intelligence era more and more important, requires teachers of colleges and universities have to update the teaching concept of "crisis consciousness, improving the informationization teaching of" ideology ", the informationization teaching resources sharing consciousness, break the traditional classroom teaching innovation consciousness, strengthen the model of "bear" consciousness, strengthen for students, for schools, for the society, for the "service consciousness" of national informatization development. [9] In line with the development trend of world information technology, we should master modern information teaching technology, constantly improve our information literacy, innovate traditional classroom teaching methods, improve our information teaching ability and level, and strive to make our own contribution to the development of national education information technology.

\section{ACKNOWLEDGMENT}

\section{9 teaching reform research project of} Shandong union university: Construction and implementation of the Internet of things engineering curriculum system under the new engineering background (2019xh08). 


\section{REFERENCES}

[1] Ministry of education. The ministry of education issued guidelines during the epidemic prevention and control to do a good job in the university online teaching organization and management[OL].

[2] 360 wikipedia. Information literacy. http:baike.so.com/doc/150395-158908.html

[3] Ping Luo.Research on the cultivation of modern secretary's information literacy [J]. Journal of panzhihua university,2008(05):56-57.

[4] LeiLi.How does China promote targeted poverty alleviation through education informatization [EB/OL].https://www.sohu.com/a/277133753_1002844

78.

[5] HeJun. Educational informatization: a good industry driven by policy, demand and technology [EB/OL].http://www.hejun.com/thought/research/hejun meiriguancha/201809/9581.html.

[6] The CPC central committee and the state council issued China's education modernization 2035 [J].Modern educational technology,2019,29(02):1.

[7] Golden hoe library. Information ethics and information security

[EB/OL].https://www.jinchutou.com/p-103960821.html.

[8] Education informatization 2.0 action plan of shandong province (2019-2022) [OL].

[9] JiaDongXiang. On strengthening "six kinds of consciousness" to promote the development of auditing informatization under the new situation

[EB/OL].http://www.hbaudit.gov.cn/html/sjlt/20190326 79187.shtml. 